\title{
Analisis Pengaruh Kinerja Keuangan Terhadap Harga Saham Pada Industri Konstruksi Yang Terdaftar di Bursa Efek Indonesia Periode 2012 - 2016
}

\author{
1Venny Junica Utami \\ ${ }^{1}$ Fakultas Ekonomi
}

\begin{abstract}
The results of this study indicate that Financial Performance, Risk Management and Working Capital Management Against Stock Price of Construction Industry in Indonesia Stock Exchange period 2012-2016 with the number of Fhitung 12,441 and Ftabel of 2.71, it can be seen that Fcount> Ftable is 12,441>2, 71, meaning there is a significant influence between earnings per share (EPS), price earning ratio (PER), return on equity (ROE), bi rate and cash conversion cycle (CCC) simultaneously to stock prices while the value of t arithmetic EPS of 5.494 and ttabel 1.72472 from the comparison then it can be known t count <ttabel $(5,494<1,72472)$. The conclusion is that all independent variables have significant effect on dependent variable at $\alpha=$ $5 \%$ or 0,05 and $F$ test criterion by comparing Fcount 12,441 and Ftabel 2,71, it can be seen that Fcount> Ftable is 12,441> 2,71, meaning there is a significant influence between earnings per share (EPS), price earning ratio (PER), return on equity $(R O E)$, bi rate and cash conversion cycle (CCC) simultaneously to stock price in property and real estate industry in $2012-2016$.
\end{abstract}

Keyword: financial performance, stocks, stock exchange

\section{PENDAHULUAN}

Semua perusahaan tertutup memiliki kesempatan untuk go public yang artinya menjual sebagian sahamnya kepada publik dan mencatatkan sahamnya di Bursa Efek Indonesia. Manfaat pertama bagi perusahaan adalah mendapatkan akses pendanaan untuk mengembangkan usahanya. Banyak perusahaan menemui kendala untuk mendapatkan modal usaha dan dana investasi untuk ekspansi usaha. Dengan menjadi perusahaan publik, perusahaan bisa mendapatkan dana untuk pengembangan usaha dalam jumlah yang cukup besar dengan biaya yang relatif murah. Selain itu, dengan menjadi perusahaan publik, maka perusahaan akan lebih transparan dan memiliki Good Corporate Governance (GCG). Perusahaan wajib mempublikasikan laporan keuangan secara berkala sehingga dipastikan perusahaan dapat beroperasi dengan baik. Disamping itu, jika perusahaan sudah berstatus milik publik, maka alternatif pendanaan melalui bank juga akan lebih mudah. Bank akan lebih percaya karena mudah mengakses informasi mengenai perusahaan. (Adisetiawan, 2012)

Hal ini berarti jalan bagi perusahaan untuk bertumbuh menjadi lebih besar akan terbuka dengan berstatus emiten. Perusahaan juga memiliki kesempatan untuk menerbitkan surat utang guna mencukupi kebutuhan modal, karena umumnya investor akan lebih percaya kepada perusahaan yang sudah tercatat di bursa. Untuk itu perusahaan guna menyediakan dana yang lebih besar untuk memperluas kegiatan usahanya harus menerbitkan sekuritas atau saham yang dijual kepada masyarakat umum melalui pasar modal. Sunariyah (2011:4) menyatakan pasar modal secara umum adalah suatu sistem keuangan yang terorganisasi, termasuk di dalamnya adalah bank-bank komersial dan semua lembaga perantara di 
bidang keuangan, serta keseluruhan surat-surat berharga yang beredar. Untuk menarik perhatian para investor, maka para investor membutuhkan informasi tentang kondisi kinerja keuanganperusahaan.

Kinerja keuangan adalah suatu analisis yang dilakukan untuk melihat sejauh mana suatu perusahaan telah melaksanakan dengan menggunakan aturan-aturan pelaksanaan keuangan secara baik dan benar. Seperti dengan membuat suatu laporan keuangan yang telah memenuhi standard dan ketentuan dalam PSAK (Pedoman Standar Akuntansi Keuangan) atau GAAP (General Acepted Accounting Principle) dan lainnya. Kinerja keuangan dalam penelitian ini menjadi topik utama, baik buruknya kondisi kinerja keuangan dalam suatu perusahaan dapat dilaporkan dalam bentuk laporan keuangan. Menurut Kasmir (2015:7) dalam hal laporan keuangan, sudah merupakan kewajiban setiap perusahaan untuk membuat dan melaporkan keuangan perusahaannya pada suatu periode tertentu. Untuk melakukan analisis kinerja keuangan tersebut dapat menggunakan analisis rasio fundamental. Menurut Husnan (2009:307) analisis fundamental memprediksi harga saham di masa yang akan datang dengan cara mengestimasi faktor-faktor fundamental yang mempengaruhi harga saham di masa yang akan datang dan menghubungkan variabel-variabel sehingga mengetahui perkiraan harga saham. Variabel- variable yang digunakan adalah Price Earning Ratio (PER), Return On Equity (ROE), Debtto Equity Ratio (DER), Total Assets Turnover (TATO), dan Current Ratio (CR).

Price Earning Ratio (PER) merupakan perbandingan antara harga pasar saham dengan laba per lembar saham. Return on Equity (ROE) adalah untuk mengetahui sampai seberapa jauh hasil yang diperoleh dari penanaman modalnya. Debt to Equity Ratio (DER) rasio ini merupakan perbandingan antara hutang dengan ekuitas. Total Assets Turnover (TATO) rasio ini digunakan untuk mengetahui efektivitas penggunaan asset operasi perusahaan dalam menghasilkan penjualan. Current Ratio (CR) rasio ini membandingkan antara asset lancar dengan hutang lancar (Pribadi, 2012:255-269).

Menurut Martono dan Harjito (2010:3) tinggi rendahnya harga saham banyak dipengaruhi oleh kondisi emiten. Salah satu factor yang mempengaruhi harga saham adalah kemampuan perusahaan membayar dividen, besarnya dividen ini akan mempengaruhi harga sahamnya. Apabila dividen yang dibayar tinggi, maka harga saham cenderung tinggi, sehingga nilai perusahaan juga tinggi dan sebaliknya bila dividen yang dibayarkan kecil, maka harga saham perusahaan tersebut juga rendah, sehingga nilai perusahaan rendah.

Rasio keuangan atau financial ratio ini sangat penting gunanya untuk melakukan analisa terhadap kondisi keuangan perusahaan. Bagi investor jangka pendek dan menengah pada umumnya lebih banyak tertarik kepada kondisi keuangan jangka pendek dan kemampuan perusahaan untuk membayar dividen yang memadai. Informasi tersebut dapat diketahui dengan cara yang lebih sederhana yaitu dengan menghitung rasio-rasio keuangan yang sesuai dengan keinginan.

Secara jangka panjang rasio keuangan juga dipakai dan dijadikan sebagai acuan dalam menganalisa kondisi kinerja suatu perusahaan, misalnya kondisi kinerja perusahaan selama 12 (dua belas) tahun untuk kemudian diprediksi selama 10 s.d. 12 tahun ke depan, namun analisa seperti itu jarang dilakukan. Alasannya belum tentu 
kondisi stabilitas sela 10 s.d. 12 tahun ke depan sama seperti 12 tahun yang lalu. Dalam penilaian suatu kondisi keuangan perusahaan dipengaruhi oleh faktor-faktor yang turut menyebabkan perubahan pada kondisi keuangan seperti kondisi mikro dan makro ekonomi baik yang terjadi di tingkat domestik dan internasional. Analisis rasio keuangan sendiri dimulai dengan laporan keuangan dasar yaitu dari neraca (balancesheet), perhitungan rugi laba (income statement), dan laporan arus kas (cash flow statement).

Untuk memutuskan suatu badan usaha atau perusahaan memiliki kualitas yang baik maka ada dua penilaian yang paling dominan yang dapat dijadikan acuan untuk melihat badan usaha/perusahaan tersebut telah menjalankan kaidah-kaidah manajemen yang baik. Penilaian ini dapat dilakukan dengan melihat sisi kinerja keuangan (financial performance). Kinerja keuangan melihat pada laporan keuangan yang dimiliki oleh perusahaan/ badan usaha yang bersangkutan dan itu tercermin dari informasi yang diperoleh pada balancesheet (neraca), income statement (laporan laba rugi) : 1, dan cash flow statement (laporan arus kas) serta hal-hal lain yang turut mendukung sebagai penguat penilaian financial performance tersebut.

Kinerja keuangan adalah suatu analisis yang dilakukan untuk melihat sejauh mana suatu perusahaan telah melaksanakan dengan menggunakan aturan-aturan pelaksanaan keuangan secara baik dan benar. Seperti dengan membuat suatu laporan keuangan yang telah memenuhi standardan ketentuan dalam PSAK (Pedoman Standar Akuntansi Keuangan) atau GAAP (General Acepted Accounting Principle) dan lainnya.

Rasio keuangan mengungkapkan hubungan keuangan secara numerik diantara pelaporan dalam laporan keuangan dan menggunakannya untuk membandingkan secara rasional periode saat ini terhadap periode sebelumnya. Analisis rasio dapat membimbing investor membuat keputusan atau pertimbangan tentang apa yang akan dicapai oleh perusahaan dan bagaimana prospek yang akan dihadapi di masa depan. Perusahaan yang mempunyai rasio-rasio keuangan yang baik akan membuat pihak luar beranggapan bahwa kinerja perusahaan tersebut juga baik. Artinya apabila perusahaan ditagih, perusahaan akan mampu untuk memenuhi utang tersebut terutama utang yang sudah jatuh tempo.

Analisis rasio keuangan menggunakan data laporan keuangan yang telah ada sebagai dasar penilaiannya. Meskipun didasarkan pada data dan kondisi masa lalu, analisis rasio keuangan dimaksudkan untuk menilai risiko dan peluang pada masa yang akan datang. Pengukuran dan hubungan satu pos dengan pos lain dalam laporan keuangan yang tampak dalam rasio-rasio keuangan dapat memberikan kesimpulan yang berarti dalam penentuan tingkat kesehatan keuangan suatu perusahaan. Tetapi bila hanya memperhatikan satu alat rasio saja tidaklah cukup, sehingga harus dilakukan pula analisis persaingan-persaingan yang sedang dihadapi oleh manajemen perusahaan dalam industri yang lebih luas, dan dikombinasikan dengan analisis kualitatif atas bisnis dan industri manufaktur, analisis kualitatif, serta penelitianpenelitian industri.

Harga saham suatu perusahaan mencerminkan bagaimana kinerja keuangan perusahaan, bila kinerja keuangan perusahaan baik maka harga saham cenderung naik, sebaliknya bila kinerja keuangan perusahaan turun maka harga saham akan turun. Permintaan dan penawaran mempengaruhi harga saham. Semakin tinggi harga permintaan maka harga saham akan naik, untuk meningkatkan permintaan maka 
perusahaan dapat meningkat. Secara sederhana harga saham mencerminkan perubahan minat investor terhadap saham tersebut. Jika permintaan terhadap suatu saham tinggi, maka harga saham tersebut akan cenderung tinggi. Demikian sebaliknya, jika permintaan terhadap suatu saham rendah, maka harga saham tersebut akan cenderung turun. Oleh karena itu kinerja keuangan dapat digunakan sebagai input untuk mengukur perubahan harga saham.

Menurut Syarif Hidayat Menteri Perindustrian Dunia Industri Kontruksi di Indonesia mengalami perkembangan yang begitu pesat dalam beberapa dekade terakhir. Industri kontruksi sebagai salah satu bagiannya mengalami persaingan yang semakin ketat. Menghadapi persaingan antar industri kontruksi yang semakin ketat. Perseroan melakukan redefinisi visi dan misi yakni Menjadi Industri Kontruksi Terkemuka di Asia Tenggara. Sehubungan dengan hal tersebut, industri kontruksi dituntut untuk meningkatkan efektifitas kerja dalam segala tahap proyek rekontruksi.

Industri Konstruksi di Bursa Efek Infonesia ada 14 (empat belas) perusahaan yaitu PT Acset Indonesia Tbk, PT Adhi Karya (Persero) Tbk, PT Cahayasakti Investindo Sukses Tbk, PT Nusa Konstruksi Enjiniring Tbk d.h Duta Graha Indah Tbk, PT Indonesia Pondasi Raya Tbk, PT Mitra Pemuda Tbk, PT Nusa Raya Cipta Tbk, PT Paramita Bangun Sarsan Tbk, PT Pembangunan Perumahan (Persero Tbk, PT Surya Semesta Internusa Tbk, PT Totalindo Eka Persada Tbk, PT Total Bangun Persada Tbk, PT Wijaya Karya (Persero) Tbk, dan PT Waskita Karya (Persero) Tbk.

Dari 14 (empat belas) perusahaan hanya 5 (lima) perusahaan yang menjadi sampel dalam penelitian yang dilakukan. Pemilihan 5 (lima) perusahaan diperoleh dari teknik pemilihan data laporan keuangan yang lengkap sepanjang tahun 20122016 yaitu perusahaan Adhi Karya (Persero) Tbk (ADHI), Nusa Kontruksi Enjinring Tbk (DGIK), Pembangunan Perumahan (Persero) Tbk (PTPP), Total Pembangunan Persada Tbk (TOTL), Wijaya Karya (Persero) Tbk (WIKA).

Perkembangan yang diperoleh dari setiap perusahaan maka dapat dilihat dari Pengaruh Earning Per Share (EPS) dan Price Earning Ratio (PER) terhadap harga saham pada industri kontruksi yang terdaftar di BEI pada tabel 1, 2, 3berikut:

\section{Tabel 1}

DataEarning Per Share (EPS) Pada Industri Kontruksi yang terdaftar di Bursa Efek Indonesia Periode 2012-2016

\begin{tabular}{cccccccc}
\hline \multirow{2}{*}{ Perusahaan } & $\mathbf{2 0 1 2}$ & $\mathbf{2 0 1 3}$ & $\mathbf{2 0 1 4}$ & $\mathbf{2 0 1 5}$ & $\mathbf{2 0 1 6}$ & Jumlah & Rata-rata \\
\hline ADHI & 118,42 & 226,74 & 184,12 & 130,59 & 88,49 & 748,36 & 149,67 \\
DGIK & 8,57 & 11,93 & 11,02 & 0,84 & 1,31 & 33,67 & 6,73 \\
PTPP & 63,95 & 86,88 & 109,88 & 174,62 & 185,72 & 621,05 & 124,21 \\
TOTL & 53,29 & 62,51 & 48,02 & 56,10 & 46,58 & 226,5 & 53,3 \\
WIKA & 82,73 & 101,69 & 122,10 & 114,32 & 127,89 & 548,73 & 109,74 \\
Jumlah & 326,96 & 489,75 & 475,36 & 476,47 & 449,99 & $2.178,3$ & 443,65 \\
Rata-rata & 65,39 & 97,95 & 91,47 & 95,29 & 89,99 & 435,66 & 88,73 \\
Perkembangan & - & 49,78 & $(6,61)$ & 4,22 & $(5,55)$ & & \\
\hline
\end{tabular}

Sumber:laporan keuangan industri konstruksi periode 2012-2016

Berdasarkan tabel 1 diatas mengenai Earning Per Sharepada Industri Kontruksi yang terdaftar di Bursa Efek Indonesia selama periode 2012-2016, mengalami perkembangan yang cenderung menurun. Dimana nilai perkembangan tertinggi 
terdapat pada tahun 2013 dengan persentase 49,78\%, sedangkan nilai perkembangan terendah pada tahun 2014 dengan nilai minus 6,61\%.

Selain Earning Per Share untuk memprediksi nilai perusahaan yang diukur dapat juga menggunakan Price Earning Ratio pada tabel 2berikut ini:

Tabel 2

Data Price Earning Ratio (PER) Pada Industri Kontruksi yang terdaftar di Bursa Efek Indonesia Periode 2012-2016

\begin{tabular}{cccccccc}
\hline \multirow{2}{*}{ Perusahaan } & $\mathbf{2 0 1 2}$ & \multicolumn{7}{c}{ Price Earning Ratio (PER) $\mathbf{2 0 )}$} \\
& 6,70 & ADHI & 6,70 & ADHI & 6,70 & ADHI & 2012 \\
\hline ADHI & 12,57 & DGIK & 12,57 & DGIK & 12,57 & DGIK & 12,57 \\
DGIK & 13,35 & PTPP & 13,35 & PTPP & 13,35 & PTPP & 13,35 \\
PTPP & 8,78 & TOTL & 8,78 & TOTL & 8,78 & TOTL & 8,78 \\
TOTL & 17,02 & WIKA & 17,02 & WIKA & 17,02 & WIKA & 17,02 \\
WIKA & 58,42 & Jumlah & 58,42 & Jumlah & 58,42 & Jumlah & 58,42 \\
Jumlah & 11,68 & Rata-rata & 11,68 & Rata-rata & 11,68 & Rata-rata & 11,68 \\
Rata-rata & - & Perkembangan & - & Perkembangan & - & Perkembangan & - \\
Perkembangan & - &
\end{tabular}

Sumber:laporan keuangan industri konstruksi periode 2012-2016

Berdasarkan tabel 2 diatas mengenai Price Earning Ratio pada Industri Kontruksi yang terdaftar di Bursa Efek Indonesia selama periode 2012-2016, mengalami perkembangan yang cenderung naik. Dimana nilai perkembangan tertinggi terdapat pada tahun 2013 dengan persentase 185,95\%, sedangkan nilai perkembangan terendah pada tahun 2014 dengan nilai minus $22,75 \%$.

Selain Price Earning Ratio untuk memprediksi nilai perusahaan yang diukur dapat juga menggunakan Return On Equity pada tabel 3 berikut ini :

\section{Tabel 3}

Data Return On Equity (ROE) Pada Industri Kontruksi yang terdaftar di Bursa Efek Indonesia Periode 2012-2016

\begin{tabular}{cccccccc}
\hline \multirow{2}{*}{ Perusahaan } & \multicolumn{7}{c}{ Return On Equity (ROE) $(\%)$} \\
& 2012 & 2013 & 2014 & 2015 & 2016 & Jumlah & Rata-rata \\
\hline ADHI & 18,06 & 26,38 & 18,94 & 9,01 & 5,79 & 78,18 & 15,63 \\
DGIK & 4,71 & 6,23 & 5,53 & 0,43 & 0,66 & 17,56 & 3,51 \\
PTPP & 18,70 & 21,20 & 22,26 & 16,52 & 10,67 & 89,35 & 17,87 \\
TOTL & 25,75 & 26,03 & 20,49 & 22,08 & 17,87 & 112,22 & 22,44 \\
WIKA & 17,95 & 19,35 & 15,08 & 12,93 & 9,18 & 74,49 & 14,89 \\
Jumlah & 85,17 & 99,19 & 82,3 & 60,97 & 44,17 & 371,8 & 74,34 \\
Rata-rata & 17,03 & 19,83 & 16,46 & 12,19 & 8,83 & 74,36 & 14,86 \\
Perkembangan & - & 16,44 & $(16,99)$ & $(25,94)$ & $(27,56)$ & & \\
\hline
\end{tabular}

Sumber:laporankeuangan industrikonstruksiperiode2012-2016

Selain Return On Equity untuk memprediksi nilai perusahaan yang diukur dapat juga menggunakan BI Rate pada tabel 4 berikut ini : 
Tabel 4

Data Bank Indonesia Rate yang terdaftar di Bursa Efek Indonesia Periode 2012-2016

\begin{tabular}{ccc}
\hline Tahun & BI Rate $(\%)$ & Perkembangan \\
\hline 2011 & 6,00 & - \\
2012 & 5,75 & $-4,1$ \\
2013 & 7,50 & 30,43 \\
2014 & 7,75 & 3,33 \\
2015 & 7,50 & $-3,22$ \\
2016 & 6,50 & $-13,33$ \\
Jumlah & 41 & 13,11 \\
Rata-rata & 8,2 & - \\
\hline
\end{tabular}

Sumber : $\underline{w w w . b i r a t e . c o . i d}$

Berdasarkan tabel 4 diatas mengenai BI Rate pada Bank Indonesia yang terdaftar di Bursa Efek Indonesia selama periode 2012-2016, mengalami perkembangan yang cenderung menurun. Dimana nilai perkembangan tertinggi terdapat pada tahun 2013 dengan persentase 30,43\%, sedangkan nilai perkembangan terendah pada tahun 2016 dengan nilai minus 13,33\%.Selain BI Rate untuk memprediksi nilai perusahaan yang diukur dapat juga menggunakan Cash Conversion Cycle pada tabel 5 berikut ini :

\section{Tabel 5}

Data Cash Conversion Cycle (CCC) Industri Kontruksi yang terdaftar di Bursa Efek Indonesia Periode 2012-2016

\begin{tabular}{cccccccc}
\hline \multirow{2}{*}{ Perusahaan } & $\mathbf{2 0 1 2}$ & $\mathbf{2 0 1 3}$ & $\mathbf{2 0 1 4}$ & $\mathbf{2 0 1 5}$ & $\mathbf{2 0 1 6}$ & Jumlah & Rata-rata \\
\hline ADHI & $(125,4)$ & $(102,2)$ & $(99,1)$ & $(152,7)$ & $(256,6)$ & $(736,7)$ & $(147,3)$ \\
DGIK & 60,6 & 41 & 36,1 & 43,4 & 63,3 & 224,5 & 48,9 \\
PTPP & $(4204,9)$ & $(12.709)$ & $(5.041)$ & $6.375,6$ & $2.296,1$ & $(13.283)$ & $(2.656)$ \\
TOTL & 70,8 & 63,0 & 106,7 & 71,8 & 84,2 & 396,8 & 79,3 \\
WIKA & $(32,4)$ & $(42,9)$ & $(56,2)$ & $(32,3)$ & $(85)$ & $(249)$ & $(49,8)$ \\
Jumlah & $(4.231)$ & $(12.749)$ & $(5.053)$ & $6.305,8$ & 2.102 & $(13.647)$ & $(2.725)$ \\
Rata-rata & $(846,2)$ & $(2.549)$ & $(1.010,7)$ & $1.261,1$ & 420,4 & $(2.729)$ & $(545,1)$ \\
Perkembangan & - & $(201)$ & $(139,6)$ & 24,7 & $(66,6)$ & & \\
\hline
\end{tabular}

Sumber:laporan keuangan industri konstruksi periode 2012 - 2016

Berdasarkan tabel 5 diatas mengenai CCC pada Industri Kontruksi yang terdaftar di Bursa Efek Indonesia selama periode 2012-2016, mengalami perkembangan yang cenderung menurun. Dimana nilai perkembangan tertinggi terdapat pada tahun 2015 dengan persentase nilai 24,78\%, sedangkan nilai perkembangan terendah pada tahun 2013 dengan nilai minus 201,31\%.Selain Cash Conversion Cycle untuk melihat Harga Saham pada tabel 6 berikut ini 
Tabel 6

Data Harga Saham Pada Industri Kontruksi yang terdaftar di Bursa Efek Indonesia Periode 2012-2016

\begin{tabular}{cccccccc}
\hline \multirow{2}{*}{ Perusahaan } & $\mathbf{2 0 1 2}$ & $\mathbf{2 0 1 3}$ & $\mathbf{2 0 1 4}$ & $\mathbf{2 0 1 5}$ & $\mathbf{2 0 1 6}$ & Jumlah & Rata-rata \\
\hline ADHI & 1.281 & 2.953 & 2.140 & 2.080 & 2.100 & 10.554 & $2.110,8$ \\
DGIK & 150 & 179 & 85 & 55 & 94 & 563 & 112,6 \\
PTPP & 1.103 & 3.398 & 3.683 & 3.810 & 3.590 & 15.584 & $3.116,8$ \\
TOTL & 500 & 1.120 & 615 & 765 & 770 & 3.770 & 754 \\
WIKA & 1.463 & 3.408 & 2.445 & 2.360 & 2.570 & 12.246 & $2.449,2$ \\
Jumlah & 4.497 & 11.058 & 8.968 & 9.070 & 9.124 & 42.717 & $8.543,4$ \\
Rata-rata & 899.4 & $2.211,6$ & $1.793,6$ & 1.814 & $1.824,8$ & $8.543,4$ & $1.708,6$ \\
Perkembangan & - & 145.89 & $(18.90)$ & 1.13 & 0.59 & & \\
\hline
\end{tabular}

Sumber:laporan keuangan industri konstruksi periode 2012-2016

Berdasarkan tabel 6 diatas mengenai Harga Sahampada Industri Kontruksi yang terdaftar di Bursa Efek Indonesia selama periode 2012-2016, mengalami perkembangan yang cenderung naik. Dimana nilai perkembangan tertinggi terdapat pada tahun 2013 dengan persentase 145,89\%, sedangkan nilai perkembangan terendah pada tahun 2014 dengan nilai minus 18,90\%.

Dengan melihat pentingnya informasi rasio-rasio keuangan perusahaan, maka perlu untuk ditelusuri apakah Erning Per Share (EPS), Price Earning Ratio (PER) dan Return On Equity (ROE), BI Rate, Cash Conversion Cycle (CCC) mempunyai pengaruh terhadap harga saham. Menurut pendapat Siswanti Manulang, 2014 bahwa rasio profitabilitas EPS secara parsial tidak memiliki pengaruh yang signifikan terhadap harga saham. Sedangkan menurut Sartika, 2012 bahwa DER, PER, dan ROE secara simultan mempunyai pengaruh yang signifikan terhadap harga saham, sedangkan secara parsial juga mempunyai pengaruh yang signifikan. Dan menurut Yani Tri Agustina, 2009 bahwa EPS secara partial memiliki pengaruh positif dan signifikan terhadap harga saham sedangkan PER berpengaruh positif dan tidak signifikan terhadap perubahan harga saham.

\section{METODE}

Populasi dalam penelitian ini adalah seluruh perusahaan manufaktur yang go public di Indonesia yang terdaftar di BEI pada tahun 2012 sampai dengan tahun 2016. Sampel yang digunakan dalam penelitian ini adalah Industri konstruksiyang memiliki kriteria tertentu. Metode pengambilan sampel yang digunakan adalah inklusi sampling dimana pengambilan perusahaan sampel dilakukan berdasarkan kriteria sebagai berikut:

1. Emiten yang listing di Bursa Efek Indonesia periode 2012-2016

2. Emiten yang terdaftar dalam industri konstruksi di Bursa Efek Indonesia periode 2012-2016

3. Memiliki laporan keuangan yag lengkap selama periode pengamatan

Berdasarkan kriteria diatas maka dari 14 perusahaan yang ada di industri konstruksi yang diambil hanya 5 perusahaan yaitu Adhi Karya (Persero) Tbk (ADHI), Nusa Kontruksi Enjinring Tbk (DGIK), Pembangunan Perumahan (Persero) Tbk (PTPP), Total Pembangunan Persada Tbk (TOTL), Wijaya Karya (Persero) Tbk (WIKA). 
Dalam penelitian ini, metode yang digunakan adalah metode kuantitatif, menurut Indiantoro dan Supomo (1999:78) penelitian kuantitatif adalah penelitian yang menekan pada pengujian teori-teori melalui pengungkapan variabel-variabel penelitian dengan angka dan melakukan analisa data dengan prosedur statistik. Tujuan dari penelitan kuantitatif ini adalah untuk menganalisis bagaimana pengaruh earning per share, price earning ratio, return on equity, bi rate, cash conversation cyclemempengaruhi harga saham. Metode analisis yang digunakan adalah analisis regresi linear berganda.

\section{Operasional Variabel}

Operasional variabel penelitian ini adalah sebagai berikut :

\section{Tabel 7}

Operasional variabel

\begin{tabular}{|c|c|c|c|c|}
\hline Variabel & Definisi & Formula & Satuan & $\begin{array}{c}\text { Skala } \\
\text { Pengukuran }\end{array}$ \\
\hline $\begin{array}{l}\text { Earning Per } \\
\text { Share } \\
\left(\mathrm{X}_{1}\right)\end{array}$ & $\begin{array}{l}\text { Earning Per Share } \\
\text { (EPS) merupakan rasio } \\
\text { yang menunjukkan } \\
\text { bagian laba untuk setiap } \\
\text { saham(Darmadji dan } \\
\text { Fakhruddin, 2011:154). }\end{array}$ & $\frac{\text { LabaBersih }}{\text { JumlahSahamBeredar }}$ & $\mathrm{Rp}$ & Rasio \\
\hline $\begin{array}{c}\text { Price Earning } \\
\text { Ratio } \\
\left(\mathrm{X}_{2}\right)\end{array}$ & $\begin{array}{l}\text { PER (Price Earning } \\
\text { Ratio) adalah } \\
\text { menggambarkan } \\
\text { apresiasi pasar terhadap } \\
\text { kemampuan perusahaan } \\
\text { dalam menghasilkan } \\
\text { laba (Darmadji dan } \\
\text { Fakhruddin, 2011:156) }\end{array}$ & $\frac{\text { HargaPasarSaham }}{\text { LabaBersihPerSaham }}$ & $\%$ & Rasio \\
\hline $\begin{array}{l}\text { Return On } \\
\text { Equity } \\
\left(\mathrm{X}_{3}\right)\end{array}$ & $\begin{array}{l}\text { Return On Equity } \\
\text { (ROE) merupakan rasio } \\
\text { untuk mengukur laba } \\
\text { bersih sesudah pajak } \\
\text { dengan modal sendiri } \\
\text { (Kasmir,2014:204) }\end{array}$ & $\frac{\text { LabaBersih }}{\text { ModalSendiri }}$ & $\%$ & Rasio \\
\hline
\end{tabular}

\section{HASIL}

\section{Uji Normalitas}

Menurut Ghozali (2011:86) uji normalitas bertujuan untuk menguji apakah dalam model regresi, variabel pengganggu atau residual memiliki distribusi normal. Dalam uji normalitas ini ada 2 cara untuk mendeteksi apakah residual berdistribusi normal atau tidak, yaitu dengan analisis grafik dan uji statistik. Alat uji yang digunakan dengan analisis ini adalah uji statistik dengan Kolmogorov-Smirnov Z (1Sample K-S) adalah sebagai berikut: 


\section{Tabel 8}

Uji Normalitas

One-Sample Kolmogorov-Smirnov Test

\begin{tabular}{|l|l|r|}
\hline \multicolumn{2}{|c|}{} & \multicolumn{2}{c|}{ Unstandardized Residual } \\
\hline $\mathrm{N}$ & Mean & 25 \\
\hline \multirow{2}{*}{ Normal Parameters ${ }^{\mathrm{a}, \mathrm{b}}$} & Std. Deviation &, 48371275 \\
\hline \multirow{3}{*}{ Most Extreme Differences } & Absolute &, 156 \\
\cline { 2 - 3 } & Positive &, 156 \\
\cline { 2 - 3 } & Negative &,- 113 \\
\hline Kolmogorov-Smirnov Z & &, 781 \\
\hline Asymp. Sig. (2-tailed) &, 576 \\
\hline
\end{tabular}

\section{Sumber :Data Diolah}

Tabel 8 diatas menjelaskan bahwa variabel EPS, PER, ROE, BI Rate, dan CCC memiliki nilai Asymp. Sig. sebesar 0,576 artinya nilai Asymp. Sig. lebih besar $\alpha=$ 0,05 sehingga dapat dikatakan bahwa variabel EPS, PER, ROE, BI Rate, dan CCC berdistribusi normal.

\section{Uji Multikolinearitas}

Uji multikolinearitas bertujuan untuk mengetahui apakah pada model regresi ditemukan adanya korelasi antar variabel independen. Untuk mengetahui apakah terjadi multikolinearitas dalam suatu model regresi dapat dilihat dari nilai VIF (Variance Inflation Factor). Apabila nilai tolerance < 0,1 dan VIF $>10$ (Variance Inflation Factor) mengindikasikan terjadi multicollinearity (Ghozali, 2011:97) adalah sebagai berikut:

Tabel 9

Uji Multikolinearitas

Coefficients $^{\mathbf{a}}$

\begin{tabular}{|c|c|c|c|c|c|c|c|c|c|}
\hline \multirow[t]{2}{*}{ Model } & \multicolumn{2}{|c|}{$\begin{array}{l}\text { Unstandardized } \\
\text { Coefficients }\end{array}$} & \multirow{2}{*}{$\begin{array}{c}\text { Standardized } \\
\text { Coefficients }\end{array}$} & \multirow[t]{2}{*}{$\mathrm{T}$} & \multirow{2}{*}{$\begin{array}{l}\text { Sig. } \\
\text { Lower } \\
\text { Bound }\end{array}$} & \multicolumn{2}{|c|}{$\begin{array}{c}95,0 \% \\
\text { Confidence } \\
\text { Interval for B }\end{array}$} & \multicolumn{2}{|c|}{$\begin{array}{l}\text { Collinearity } \\
\text { Statistics }\end{array}$} \\
\hline & B & $\begin{array}{l}\text { Std. } \\
\text { Error }\end{array}$ & & & & $\begin{array}{l}\text { Lower } \\
\text { Bound }\end{array}$ & $\begin{array}{l}\text { Upper } \\
\text { Bound }\end{array}$ & $\begin{array}{c}\text { Toleran } \\
\text { ce }\end{array}$ & VIF \\
\hline (Constant) & $\begin{array}{r}3,702 \mathrm{E}- \\
011\end{array}$ & 109 & & , 000 & 1,000 & ,228 & ,228 & & \\
\hline EPS & ,795 & , 145 & ,795 & 5,494 &, 000 & ,492 & 1,097 & ,589 & 1,698 \\
\hline PER & , 172 & ,148 & , 172 & 1,156 & ,262 &,- 139 & ,482 & ,559 & 1,789 \\
\hline ROE & ,027 & , 159 & ,027 & ,167 & 869 &,- 307 & ,360 & ,484 & 2,065 \\
\hline BI RATE & ,067 & , 121 & ,067 & ,553 & ,587 &,- 186 & ,320 & 841 & 1,189 \\
\hline $\mathrm{CCC}$ &,- 220 & ,126 &,- 220 & $-1,740$ & ,098 &,- 485 &, 045 & ,770 & 1,299 \\
\hline
\end{tabular}

sumber :Data Diolah

Tabel 9 diatas menjelaskan bahwa nilai VIF variabel EPS sebesar 1,698, variabel PER sebesar 1,789, variabel ROE sebesar 2,065, variabel BI Rate sebesar 1,189, dan variabel CCC sebesar 1,299 sehingga dapat dikatakan variabel tersebut tidak terdapat multikolinearitas dikarenakan nilai VIF dari semua variabel lebih besar dari nilai tolerance $<0,1$ dan VIF $<10$. 


\section{Uji Heteroskedastisitas}

Uji heterokesdatisitas bertujuan untuk mengetahui apakah dalam sebuah model regresi terjadi ketidaksamaan varians dari residual suatu pengamatan ke pengamatan lain. Jika varians dari residual suatu pengamatan ke pengamatan yang lain tetap, maka disebut homoskedastisitas, sementara itu, untuk varians yang berbeda disebut heteroskedastisitas. Mendeteksi ada atau tidaknya heterokedatisitas adalah dengan melihat grafik plot antara nilai prediksi variabel dependen yaitu ZPRED dengan residualnya SPRESID. Deteksi ada tidaknya heterokedatisitas dapat dilakukan dengan melihat ada tidaknya pola tertentu pada grafik scatterplot antara SPRESID dan ZPREDdimana sumbu X adalah $\breve{Y}$ (Y yang telah diprediksi (ZPRED)dan sumbu $\mathrm{Y}$ adalah residual atau SPRESID ( $\mathrm{Y}-\mathrm{Y}$ ) yang telah distudentized(Ghozali, 2011:102).

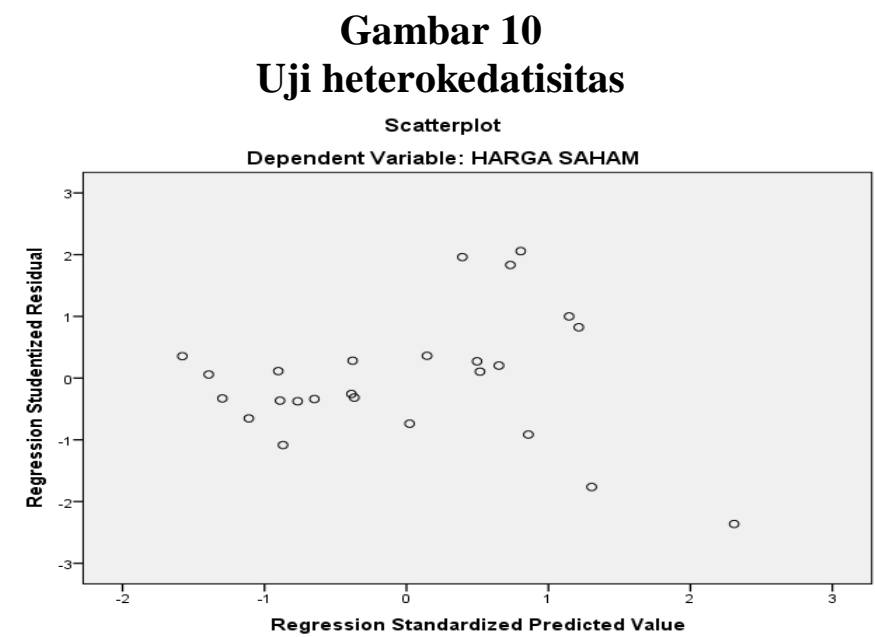

Berdasarkan gambar 10 menunjukkan bahwa grafik scatterplot terlihat bahwa titik-titik menyebar secara acak serta tersebar baik diatas maupun dibawah angka 0 pada sumbu Y dan titik tidak membentuk suatu pola tertentu. Hal ini dapat dikatakan bahwa tidak terjadi heteroskedastisitas pada model regresi, sehingga model regresi layak untuk diuji.

\section{Uji Autokolerasi}

Uji autokorelasi bertujuan untuk menguji apakah dalam modalregresilinear ada korelasi antara kesalahan pengganggu (residual) padaperiode $\mathrm{t}$ dengan kesalahan penganggu pada periode t-1 (sebelumnya). Jika terjadi korelasi maka dinamakan ada problem autokorelasi. Model regresi yang baik adalah regresi bebas dari autokorelasi. Untuk mengetahui tidak terjadinya Autokorelasi dilakukan pengujian dengan Run Test sebagai bagian dari statistik non-parametrik dapat pula digunakan untuk menguji apakah antar residual terdapat korelasi yang tinggi. Jika antar residual tidak terdapat hubungan korelasi maka dikatakan bahwa residual adalah acak atau random. Run Test digunakan untuk melihat apakah data residual terjadi secara random atau tidak (sistematis). Apabila nilai signifikansi kurang dari signifikansi 0,05 yang berarti hipotesis nol ditolak, sehingga dapat disimpulkan bahwa residual tidak random atau terjadi autokorelasi antar nilai residual (Imam Ghazali,2012:120). 
HO : Data residual berdistribusi normal

HA : Data residual tidak berdistribusi normal

Tabel 11

Uji Autokolerasi

Runs Test

\begin{tabular}{|l|r|}
\hline & Unstandardized Residual \\
\hline Test Value &, 02616 \\
Cases $<$ Test Value & 12 \\
Cases >= Test Value & 13 \\
Total Cases & 25 \\
Number of Runs & 18 \\
Z & 1,645 \\
Asymp. Sig. (2-tailed) &, 100 \\
\hline
\end{tabular}

Sumber :Data Diolah

Tabel 11 diatas menjelaskan bahwa variabel EPS, PER, ROE, BI Rate, dan CCC memiliki nilai Asymp. Sig. sebesar 0,100 artinya nilai Asymp. Sig. lebih besar $\alpha=0,05$ sehingga dapat dikatakan bahwa variabel EPS, PER, ROE, BI Rate, dan $\mathrm{CCC}$ tidak terdapat autokolerasi sehingga $\mathrm{H} 0$ diterima dan HA ditolak.

\section{Regresi Linear Berganda}

Analisis regresi berganda dimaksudkan untuk menguji pengaruh simultan dari beberapa variabel bebas terhadap satu variabel terikat :

\section{Tabel 12}

\section{Hasil Pengujian Regresi Linear Berganda} Coefficients $^{\mathrm{a}}$

\begin{tabular}{|c|c|c|c|c|c|}
\hline \multirow[t]{2}{*}{ Model } & \multicolumn{2}{|c|}{ Unstandardized Coefficients } & \multirow{2}{*}{$\begin{array}{c}\begin{array}{l}\text { Standardized } \\
\text { Coefficients }\end{array} \\
\text { Beta }\end{array}$} & \multirow[t]{2}{*}{$\mathrm{t}$} & \multirow[t]{2}{*}{ Sig. } \\
\hline & $\mathrm{B}$ & Std. Error & & & \\
\hline (Constant) & $3,702 \mathrm{E}-011$ &, 109 & & ,000 & 1,000 \\
\hline EPS &, 795 & 145 & ,795 & 5,494 &, 000 \\
\hline PER & 172 & ,148 & 172 & 1,156 & ,262 \\
\hline ROE &, 027 & , 159 & ,027 &, 167 & ,869 \\
\hline BI RATE & ,067 & , 121 &, 067 &, 553 &, 587 \\
\hline $\mathrm{CCC}$ &,- 220 & 126 &,- 220 & $-1,740$ & ,098 \\
\hline
\end{tabular}

Berdasarkan hasil pengujian dengan menggunakan alat analisis regresi berganda diperoleh Model regresi sebagai berikut :

$\mathrm{Y}=3,702+0,795 X 1+0,172 X 2+0,027 X 3+0,067-0,220+0,234$

Dari model regresi tersebut dapat dijelaskan :

1. $\alpha=$ konstanta sebesar 3,702, artinya variabel independen yaitu earning per share, price earning ratio, return on equity, bi rate dan cash conversion cycle dianggap konstan (bernilai 0), maka variable dependen yaitu harga saham bernilai positif sebesar 3,702. 
2. Earning Per Share (EPS) sebesar 0,795, artinya variabel EPS mengalami kenaikan sebesar 1 (satu) satuan sedangkan variabel lainnya dianggap konstan, maka variabel dependen yaitu harga saham akan mengalami peningkatan sebesar 0,795 .

3. Price Earning Ratio (PER) sebesar 0,172, artinya apabila variabel PER mengalami kenaikan sebesar $1 \%$ sedangkan variabel lainnya dianggap konstan, maka variabel dependen yaitu harga saham akan mengalami kenaikan sebesar 0,172 .

4. Return On Equity (ROE) sebesar 0,027, artinya apabila variabel ROE mengalami kenaikan sebesar $1 \%$ sedangkan variabel lainnya dianggap konstan, maka variabel dependen yaitu harga saham akan mengalami kenaikan sebesar 0,027.

5. BI Rate sebesar 0,067, artinya apabila variabel BI Rate mengalami kenaikan sebesar $1 \%$ sedangkan variabel lainnya dianggap konstan, maka variabel dependen yaitu harga saham akan mengalami kenaikan sebesar 0,067.

6. Cash Conversion Cycle (CCC) sebesar -0,220, artinya apabila variabel CCC mengalami penurunan sebesar $1 \%$ sedangkan variabel lainnya dianggap konstan, maka variabel dependen yaitu harga saham akan mengalami penurunan sebesar 0,220 .

\section{Hasil Pengujian Hipotesis}

Uji F Statistik

Uji simultan digunakan untuk mengetahui apakah variabel independen secara simultan mempengaruhi variabel dependen. Hasil uji $\mathrm{F}$ dalam penelitian dapat dilihat pada tabel dibawah ini :

Tabel 13

Hasil Pengujian Hipotesis Uji F

ANOVA $^{\mathrm{a}}$

\begin{tabular}{|rl|r|r|r|r|l|}
\hline \multicolumn{1}{|l|}{ Model } & \multicolumn{1}{|c|}{$\begin{array}{c}\text { Sum of } \\
\text { Squares }\end{array}$} & Df & \multicolumn{1}{c|}{$\begin{array}{c}\text { Mean } \\
\text { Square }\end{array}$} & F & Sig. \\
\hline \multirow{2}{*}{1} & Regression & 18,385 & 5 & 3,677 & 12,441 &, $000^{\mathrm{b}}$ \\
& Residual & 5,615 & 19 &, 296 & & \\
& Total & 24,000 & 24 & & & \\
\hline
\end{tabular}

a. Dependent Variable: HARGA SAHAM

b. Predictors: (Constant), CCC, BI RATE, ROE, EPS, PER

Sumber :Data Diolah

Secara simutan seluruh variabel bebas berpengaruh signifikan terhadap variabel terikat pada $\alpha=5 \%$ atau 0,05 dan kriteria uji $\mathrm{F}$ dengan membandingkan $F_{\text {hitung }}$ sebesar 12,441 dan $F_{\text {tabel }}$ sebesar 2,71, maka dapat dilihat bahwa $F_{\text {hitung }}>F_{\text {tabel }}$ yaitu $12,441>2,71$, artinya terdapat pengaruh signifikan antara variabel earning per share (EPS), price earning ratio (PER), return on equity (ROE), bi rate dan cash conversion cycle (CCC)secara simultan terhadap harga saham pada industri Property and Real Estateperiode 2012-2016 


\section{Uji $t$ Statistik}

Uji $\mathrm{t}$ digunakan untk mengetahui apakah variabel independen berpengaruh signifikan secara parsial terhadap variabel dependen. Tingkat signifikan menggunakan $\alpha=5 \%$ adalah ukuran standar yang sering digunakan dalam penelitian. Dalam penelitian ini menggunkan uji dua sisi yang dimana $\alpha / 2(0,05 / 2=0,025)$ dengan derajat kebebasan (df) n-k-1 atau 34-3-1 = 30 (n adalah jumlah data, k adalah jumlah variabel independen). Maka $t_{\text {tabel }}(\alpha=0,025, \mathrm{df}=31)$ diperoleh sebesar 2,042. berikut :

Hasil pengujian Uji $\mathrm{t}$ dari penelitian ini dapat dilihat pada Tabel 4.6 sebagai

\section{Tabel 14}

\section{Hasil Pengujian Hipotesis Uji t}

Coefficients $^{\mathrm{a}}$

\begin{tabular}{|l|r|r|r|r|r|}
\hline \multirow{2}{*}{ Model } & \multicolumn{2}{|c|}{ Unstandardized Coefficients } & \multicolumn{1}{c|}{$\begin{array}{l}\text { Standardized } \\
\text { Coefficients }\end{array}$} & \multicolumn{1}{c|}{ Sig. } \\
\cline { 2 - 4 } & \multicolumn{1}{|c|}{ B } & Std. Error & \multicolumn{1}{c|}{ Beta } & & \\
\hline (Constant) & $3,702 E-011$ &, 109 & &, 000 & 1,000 \\
\hline EPS &, 795 &, 145 &, 795 & 5,494 &, 000 \\
\hline PER &, 172 &, 148 &, 172 & 1,156 &, 262 \\
\hline ROE &, 027 &, 159 &, 027 &, 167 &, 869 \\
\hline BI RATE &, 067 &, 121 &, 067 &, 553 &, 587 \\
\hline CCC &,- 220 &, 126 &,- 220 & $-1,740$ &, 098 \\
\hline
\end{tabular}

a. Dependent Variable: HARGA SAHAM

Sumber :Data Diolah

Berdasarkan tabel diatas dengan nilai thitung dapat diketahui bahwa secara parsial besarnya pengaruh Earning Per Share (EPS) sebesar 5,494, Price Earning Ratio(PER) sebesar 1,156, Return On Equity (ROE) sebesar 0,167, BI Ratesebesar 0,553 dan Cash Conversion Cycle (CCC) sebesar -1,740. Pengujian statistik t

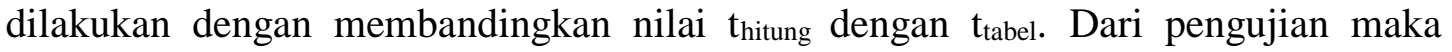
dijelaskan sebagai berikut:

1. Pengujian Hipotesis Earning Per Share (EPS)

Nilai $t_{\text {hitung }}$ variabel EPS sebesar 5,494 dan $t_{\text {tabel }} 1,72472$ dari hasil perbandingan maka dapat diketahui $t_{\text {hitung }}<\mathrm{t}_{\text {tabel }}(5,494<1,72472)$. Dapat dilihat dari signifikan EPS sebesar 0,000 lebih kecil dari $\alpha=0,05$. Maka Ho ditolak Ha diterima artinya ada pengaruh yang signifikan dari variabel EPS secara parsial terhadap harga saham pada industri Konstruksiselama periode 2012-2016.

2. Pengujian Hipotesis Price Earning Ratio (PER)

Nilai thitung variabel PER sebesar 1,156 dan $t_{\text {tabel }}$ 1,72472 dari hasil perbandingan maka dapat diketahui $t_{\text {hitung }}<t_{\text {tabel }}(1,156<1,72472)$. Dapat dilihat dari signifikan PER sebesar 0,262 lebih besar dari $\alpha=0,05$. Maka Ho terima Ha ditolak artinya tidak ada pengaruh yang signifikan dari variabel PER secara parsial terhadap harga saham pada industri Konstruksiselama periode 2012-2016.

3. Pengujian Hipotesis Retun On Equity (ROE)

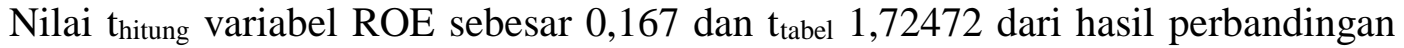
maka dapat diketahui $t_{\text {hitung }}<\mathrm{t}_{\text {tabel }}(0,167<1,72472)$. Dapat dilihat dari signifikan ROE sebesar 0,869 lebih besar dari $\alpha=0,05$. Maka Ho diterima Ha ditolak artinya 
tidak ada pengaruh yang signifikan dari variabel ROE secara parsial terhadap harga saham pada industri Konstruksi selama periode 2012-2016.

4. Pengujian Hipotesis BI Rate

Nilai $t_{\text {hitung }}$ variabel $B I$ Rate sebesar 0,553 dan $\mathrm{t}_{\text {tabel }} 1,72472$ dari hasil perbandingan maka dapat diketahui $t_{\text {hitung }}<t_{\text {tabel }}(0,553<1,72472)$. Dapat dilihat dari signifikan BI Rate sebesar 0,587 lebih besar dari $\alpha=0,05$. Maka Ho terima Ha ditolak artinya tidak ada pengaruh yang signifikan dari variabel BI Rate secara parsial terhadap harga saham pada industri Konstruksiselama periode 2012-2016.

5. Pengujian Hipotesis Cash Conversion Cycle (CCC)

Nilai thitung variabel CCC sebesar $-1,740$ dan $t_{\text {tabel }}$ 1,72472 dari hasil perbandingan maka dapat diketahui $t_{\text {hitung }}<\mathrm{t}_{\text {tabel }}(-1,740<1,72472)$. Dapat dilihat dari signifikan CCC sebesar 0,098 lebih besar dari $\alpha=0,05$. Maka Ho terima Ha ditolak artinya tidak ada pengaruh yang signifikan dari variabel CCC secara parsial terhadap harga saham pada industri Konstruksi selama periode 2012-2016.

\section{Koefisien Determinasi $\left(\boldsymbol{R}^{2}\right)$}

Uji koefisien determinasi digunakan untuk mengukur seberapa jauh kemampuan model dalam menerangkan variasi variabel independen terhadap variabel dependen.

Tabel 15

Koefisien Determinasi

\begin{tabular}{|c|c|c|c|c|}
\hline Model & $\mathrm{R}$ & $\mathrm{R}$ Square & $\begin{array}{c}\text { Adjusted } \\
\text { R Square }\end{array}$ & $\begin{array}{c}\text { Std. Error of } \\
\text { the Estimate }\end{array}$ \\
\hline 1 &, $875^{\mathrm{a}}$ &, 766 &, 704 &, 54365 \\
\hline
\end{tabular}

a. Predictors: (Constant), CCC, BI RATE, ROE, EPS, PER

b. Dependent Variable: HARGA SAHAM

Sumber :Data Diolah

Berdasarkan pengujian koefisien determinasi pada tabel 15 menunjukkan bahwa R Squre sebesar 0,766 yang artinya bahwa variabilitas variabel dependen yang dapat dijelaskan oleh variabel independen yaitu earning per share, price earning ratio, return on equity, bi rate dan cash conversion cycle dalam penelitian ini sebesar $76,6 \%$ sedangkan sisanya $23,4 \%$ dijelaskan oleh variabel lain diluar model penelitian.

\section{PEMBAHASAN}

Penelitian ini dilakukan dengan menggunakan sampel penelitian dari 5 perusahaan yang termasuk industri Konsruksidi Bursa Efek Indonesia pada periode 2012-2016. Adapun tujuan dari penelitian ini adalah untuk mengukur dan mengetahui seberapa besar pengaruh earning per share, price earning ratio, return on equity, bi rate dan cash conversion cycle terhadap harga saham baik secara simultan ataupun secara parsial pada industri Konstruksidi Bursa Efek Indonesia (BEI) periode 20122016.

\section{PengaruhEarning Per Share, Price Earning Ratio, Return On Equity,BI Rate dan} Cash Conversion Cycle Terhadap Harga Saham Secara Simultan

Secara simutan seluruh variabel bebas berpengaruh signifikan terhadap variabel terikat pada $\alpha=5 \%$ atau 0,05 dan kriteria uji $\mathrm{F}$ dengan membandingkan $F_{\text {hitung }}$ 
sebesar 12,441 dan $F_{\text {tabel }}$ sebesar 2,71, maka dapat dilihat bahwa $F_{\text {hitung }}>F_{\text {tabel }}$ yaitu $12,441>2,71$, artinya terdapat pengaruh signifikan antara variabel earning per share (EPS), price earning ratio (PER), return on equity (ROE), bi rate dan cash conversion cycle (CCC)secara simultan terhadap harga saham pada industri Konstruksiperiode 2012-2016.

Pengaruh Earning Per Share, Price Earning Ratio, Return On Equity, BI Rate dan Cash Conversion Cycle Terhadap Harga Saham Secara Parsial

Hasil penelitian menyatakan bahwa uji hipotesis variabel EPS secara parsial berpengaruh positif dan signifikan terhadap harga saham, karena menunjukkan bahwa EPS dan harga saham berkorelasi secara positif. Artinya EPS yang tinggi akan menaikan harga saham seperti yang dikemukakan Darmadji dan Fakhruddin (2011:154) yaitu Earning Per Share (EPS) merupakan rasio yang menunjukkan bagian laba untuk setiap saham. EPS menggambarkan profitabilitas perusahaan yang tergambar pada setiap lembar saham. Makin tinggi nilai EPS tentu saja menggembirakan pemegang saham karena makin besar laba yang disediakan untuk pemegang saham dan kemungkinan peningkatan jumlah deviden yang diterima pemegang saham.

Hasil penelitian menyatakan bahwa uji hipotesis variabel PER secara parsial tidak memiliki pengaruh yang signifikan terhadap harga saham meskipun menunjukkan bahwa hasil dari uji t memiliki nilai positif akan tetapi nilai yang diperoleh lebih kecil dari t tabel, seperti yang dikemukakan oleh Darmadji dan Fakhruddin (2011:178) Price Earning Ratio menunjukkan berapa banyak uang yang harus dibayar oleh investor untuk memperoleh satu satuan moneter (misalnya dalam rupiah) laba periode berjalan. Price Earning Ratio adalah suatu analisis yang sangat populer dikalangan analisis keuangan dikarenakan kemudahannya. Para analisis pasar menggunakan rata-rata Price Earning Ratio untuk menandai tingkat harga saham secara umum.

Hasil penelitian menyatakan bahwa uji hipotesis variabel ROE secara parsial tidak memiliki pengaruh yang signifikan terhadap harga saham meskipun menunjukkan bahwa hasil dari uji t memiliki nilai positif akan tetapi nilai yang diperoleh lebih kecil dari t tabel, seperti yang dikemukakan oleh Menurut Kasmir dan Jakfar (2004:140) ROE merupakan rasio untuk mengukur laba bersih sesudah pajak dengan modal sendiri. Rasio ini menunjukkan efisiensi penggunaan modal sendiri. Semakin tinggi rasio ini semakin baik. Artinya, posisi pemilik perusahaan semakin kuat.

\section{SIMPULAN}

Sesuai dengan perumusan masalah dan tujuan penelitian, berdasarkan penelitian yang telah dilakukan dapat diperoleh kesimpulan sebagai berikut ini :

1. Secara simutan seluruh variabel bebas berpengaruh signifikan terhadap variabel terikat pada $\alpha=5 \%$ atau 0,05 dan kriteria uji $\mathrm{F}$ dengan membandingkan $F_{\text {hitung }}$ sebesar 12,441 dan $F_{\text {tabel }}$ sebesar 2,71, maka dapat dilihat bahwa $F_{\text {hitung }}>F_{\text {tabel }}$ yaitu $12,441>2,71$, artinya terdapat pengaruh signifikan antara variabel earning per share (EPS), price earning ratio (PER), return on equity (ROE), bi rate dan cash conversion cycle (CCC)secara simultan terhadap harga saham pada industri Konstruksiperiode 2012-2016.

2. Secara Parsial 
a. Pengujian Hipotesis Earning Per Share (EPS)Nilai thitung variabel EPS sebesar 5,494 dan $t_{\text {tabel }} 1,72472$ dari hasil perbandingan maka dapat diketahui $t_{\text {hitung }}<$ $\mathrm{t}_{\text {tabel }}(5,494<1,72472)$. Dapat dilihat dari signifikan EPS sebesar 0,000 lebih kecil dari $\alpha=0,05$. Maka Ho ditolak Ha diterima artinya ada pengaruh yang signifikan dari variabel EPS secara parsial terhadap harga saham pada industri Konstruksi selama periode 2012-2016.

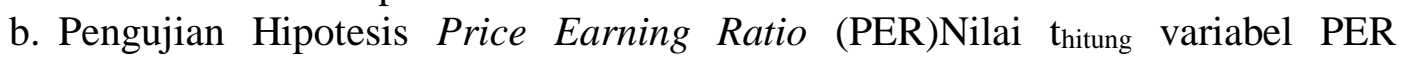
sebesar 1,156 dan $t_{\text {tabel }}$ 1,72472 dari hasil perbandingan maka dapat diketahui $\mathrm{t}_{\text {hitung }}<\mathrm{t}_{\text {tabel }}(1,156<1,72472)$. Dapat dilihat dari signifikan PER sebesar 0,262 lebih besar dari $\alpha=0,05$. Maka Ho terima Ha ditolak artinya tidak ada pengaruh yang signifikan dari variabel PER secara parsial terhadap harga saham pada industri Konstruksi selama periode 2012-2016.

c. Pengujian Hipotesis Return On Equity (ROE)Nilai thitung variabel ROE sebesar 0,167 dan tabel 1,72472 dari hasil perbandingan maka dapat diketahui $t_{\text {hitung }}<$ $\mathrm{t}_{\text {tabel }}(0,167<1,72472)$. Dapat dilihat dari signifikan ROE sebesar 0,869 lebih besar dari $\alpha=0,05$. Maka Ho diterima Ha ditolak artinya tidak ada pengaruh yang signifikan dari variabel ROE secara parsial terhadap harga saham pada industri Konstruksiselama periode 2012-2016.

d. Pengujian Hipotesis BI RateNilai thitung variabel BI Rate sebesar 0,553 dan $\mathrm{t}_{\text {tabel }}$ 1,72472 dari hasil perbandingan maka dapat diketahui $t_{\text {hitung }}<t_{\text {tabel }}(0,553<$ 1,72472). Dapat dilihat dari signifikan BI Rate sebesar 0,587 lebih besar dari $\alpha$ $=0,05$. Maka Ho terima Ha ditolak artinya tidak ada pengaruh yang signifikan dari variabel BI Rate secara parsial terhadap harga saham pada industri Konstruksiselama periode 2012-2016.

e. Pengujian Hipotesis Cash Conversion Cycle (CCC)Nilai thitung variabel CCC sebesar -1,740 dan $t_{\text {tabel }}$ 1,72472 dari hasil perbandingan maka dapat diketahui $\mathrm{t}_{\text {hitung }}<\mathrm{t}_{\text {tabel }}(-1,740<1,72472)$. Dapat dilihat dari signifikan CCC sebesar 0,098 lebih besar dari $\alpha=0,05$. Maka Ho terima Ha ditolak artinya tidak ada pengaruh yang signifikan dari variabel CCC secara parsial terhadap harga saham pada industri Konstruksi selama periode 2012-2016.

3. Berdasarkan pengujian koefisien determinasi menunjukkan bahwa R Squre sebesar 0,986 yang artinya bahwa variabilitas variabel dependen yang dapat dijelaskan oleh variabel independen yaitu debt to asset ratio, debt to equity ratio dan size dalam penelitian ini sebesar $98,6 \%$ sedangkan sisanya 1,4\% dijelaskan oleh variabel lain diluar model penelitian.

\section{Saran}

Beberapa saran yang ditujukan bagi instasi terkait dan masyarakat dalam menjalankan kegiatan perekonomian di Indonesia, serta saran bagi peneliti dan akademis dengan maksud dapat meningkatkan penelitian khusus nya di bidang industri konstruksi di Indonesia antara lain :

1. Investor perlu memperhatikan faktor-faktor dalam melakukan keputusan dalam berinvestasi di perusahaan yang akan ditanamkan modalnya, terutama pada perusahaan yang bergerak pada bidang industri konstruksi guna menghindari kerugian di kemudian hari

2. Untuk lebih memperdalam kajian dalam penelitian ini diharapkan penelitian berikutnya menambahkan variabel yang lain yang dianggap dapat mempengaruhi variabel harga saham, menambah jumlah objek penelitian baik dari segi bidang 
industri atau bidang lain agar kajian penelitian yang dihasilkan mencakup lebih luas.

3. Dalam mengelola perusahaan harus lebih baik dalam melakukan pencarian dana dari investor untuk meningkatkan keuntungan pada perusahaan, sehingga harga saham pada perusahaan tersebut mengalami kenaikan.

\section{DAFTAR PUSTAKA}

Adisetiawan, R., 2012, Relevansi Nilai Informasi Akuntansi pada Indeks LQ45, Akuntabilitas, 1(1)

Agus Harjito dan Martono.2011. Manajemen Keuangan,Edisi Kedua,Cetakan Pertama.Yogyakarta:Penerbit Ekonisia.

Bambang Supomo dan Nur Indriantoro.1991.Metodologi Penelitian Bisinis,Cetakan Kedua.Yogyakarta:Penerbit BFEE UGM.

Darmadji Tjipto dan Hendy M Fakhruddin.2001.Pasar Modal di Indonesia.Jakarta:Salemba Empat.

Ghazali,Imam.2013.Aplikasi Analisis Multivariat Dengan Program IBM SPSS 21.Edisi 7.Semarang:Penerbit Universitas Diponegoro.

Husnan,Suad.2009.Teori Portofolio dan Analisis Sekuritas.Edisi Keempat.Yogyakarta:UPP STIM YKPN.

Dr.Khasmir.2015.Analisis Laporan Keuangan.Jakarta:Rajawali Pers Sunariyah.2004.Pengantar Pengetahuan Dasar Pasar Modal.Cetak Keempat.Yogyakarta:UPP AMP YKPN. 